\title{
The Diversity of Tree Strata Vegetation in Ancient Volcano Mujil Kulon Progo Region as A Learning Source for Biology Subject in the First Grade of Senior High School
}

\author{
Trikinasih Handayani ${ }^{1 *}$, Alpendi ${ }^{2}$, Nugroho $^{3}$ \\ 1,3 Faculty of Teacher Training and Education, Universitas Ahmad Dahlan, Indonesia \\ ${ }^{2}$ Postgraduate, Universitas Negeri Yogyakarta, Indonesia \\ *Corresponding email: trikinasihhandayani@gmail.com
}

\begin{abstract}
Mount Mujil is an ancient volcano which is located in Kulon Progo district with elevation of 265 msl. Currently this area is mostly overgrown by various vegetations, in which one of them is tree strata vegetation. Researches regarding the vegetation has not been done quite much. Hence, this research aims to understand the tree strata vegetation types with the highest and lowest Important Value Index (IV), determining the variety of tree strata vegetation types, understanding the correlation between measured abiotic environment condition to the stand grouping pattern of the tree strata vegetation, determining the potential of the research result as a learning source for biology subject in first grade of senior high school in ecosystem-level biodiversity subject.

The data sampling in this research used plotless method such as Point Centered Quarter. To understand the diversity index ( $\left.\mathrm{H}^{\prime}\right)$,Shanon-Wienner Index was used, and to understand the correlation between the measured abiotic environment conditions against the stand grouping pattern, cluster analysis was used. The research result is discussed to see whether this research has potentials to be used as a learning source for biology subject in accordance to the learning source criteria.

The research result shows that there are 18 tree strata vegetation types in every study area with Tectona grandis as the highest IV $(126.48 \%)$ and Ficus septica has the lowest INP $(0.22 \%)$. The diversity index of the tree strata vegetation types is relatively low. H'ranges around $0.49-0.85$. The abiotic environmental conditions which are related to the stand grouping pattern aresoil moisture, soil $\mathrm{pH}$, and light intensity. The discussion regarding the research process and result fulfill the criteria to be a learning source for biology subject in first grade of senior high school in ecosystem-level biodiversity material.
\end{abstract}

Keywords: Biodiversity, tree strata, learning source, Mount Mujil

\section{INTRODUCTION}

Ancient volcano Mujil is located in Kulon Progo with area of around 18 hectare and top elevation at about 265 mdpl. Mount Mujil is one of the ancient volcanoes regardless of the volcano system in Kulon Progo mountains. The origin of ancient volcano Mujil have a shape of isolated conical hat and made of volcanic breccia covered by curved landscape extending to the east and filled with shallow intrusion rocks. The ancient volcano Mujil have once erupted weakly and forming a crater opening to the east. The eruption is correlated with the rock compositions which set the fractures and fragments of andesite breccia to basaltic andesite that makes Mount Mujil and its surroundings to be the remnant of an ancient volcano [1].
Based on the observation result, the ancient volcano Mujil region is a very interesting place to be deeply discussed or researched especially regarding the diversity of tree strata vegetation types in the area. The location which has not been managed by government or private parties makes the ancient volcano Mujil to be a natural location. The fact that there has not been any research regarding the diversity of the tree strata vegetation type in Ancient volcano Mujil surely makes this topic to become more interesting if it is deeply researched. Furthermore, it is not yet known regarding the potential of the biodiversity as a learning source in Biology subject especially in the subject of biodiversity in the ecosystem level. To understand and prove this aspect then a specific and deep exploration was done which gives ecology data that can be utilized as a 
learning source in biology on ecosystem level's biodiversity subject in first-grade senior high school.

One of the important components in a learning, especially in the biology learning is the availability of learning source. Based on Djohar [2] biology learning source is anything, either an object or a symptom, that can be used to obtain or increase the experience in order to solve certain biology problems. The teachers' demand in providing learning sources which can involve learning members to always be active in learning, especially biology, is highly expected. This aspect is inseparable from the 2013's curriculum which requires the creation of learning process that have a supporting atmosphere for students to be continuously active in following the learning process.

One of the methods that can be used by teachers as an alternative in providing learning resources is by developing the environment as a contextual learning source that exists around the students. One of the biology subjects that can use the environment as a contextual learning source is about the diversity in ecosystem level listed in KD 3.2 such as analyzing observed data regarding the levels of biodiversity (genes, species, and ecosystem). Various regions or environments surely have potentials to be made as a contextual learning source. One of the regions is the ancient volcano Mujil.

\section{METHOD}

The research is done in Ancient volcano Mujil Girimulyo Kulon Progo at 4-14 ${ }^{\text {th }}$ March 2019. The data sampling of tree strata vegetation analysis uses point centered quarted method, one of the plotless methods and to understand the relationship of the measured abiotic environment condition with the stand grouping pattern, cluster analysis was used. The vegetation parameter measured are density, dominance, frequency, relative density, relative dominance, relative frequency, and Important Value Index (INP). The analysis of vegetation parameter based on Mueller Dumbois\&Ellenber [3] is as follows:
a. Average distance $(\mathrm{D})=\frac{\text { Total distance }}{4 \times \text { sampling point amount }}$
b. Absolute Density

$$
\mathrm{DT}=\frac{\text { Area Unit }}{b^{2}}
$$

c. Density of each species

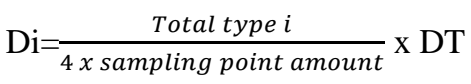

d. Relative Density

$$
\mathrm{KRi}=\frac{\text { Density } I}{D T} \times 100 \%
$$

e. Frequency I $(\mathrm{Fi})$

$\mathrm{Fi}=\frac{\text { Sampling point amount with type } i}{\text { sampling point amount }}$

f. Relative Frequency (FRi)

$$
\mathrm{FRi}=\frac{\text { Frequency } i}{\text { Total Frequency } i} \times 100 \%
$$

g. Dominance I (Di)

$\mathrm{Di}=$ Average of basal area of type $I x$ density $I$

h. Relative Dominance (DRi)

$\mathrm{DRi}=\frac{\text { Dominance } \mathrm{i}}{\text { Total Dominance }} \times 100 \%$

i. Important Value Index (INP)

$$
\mathrm{INP}=\mathrm{KRi}+\mathrm{FRi}+\mathrm{Dri}
$$

j. ID (Diversity Index) can be calculated using Shanon-Weiner formula such as:

$$
\mathrm{H}^{\prime} \quad=-\Sigma p i \log p i
$$

Annotation:

$\mathrm{H}^{\prime}=$ Shanon Index

$P i=$ The importance probability of each species

\section{RESULT AND DISCUSSION}

1. Important Value Index (INP) of tree strata in all study areas

The Important Value Index (INP) based on the researches of all tree strata vegetation types in every study area is presented in Figure 1 as follows:

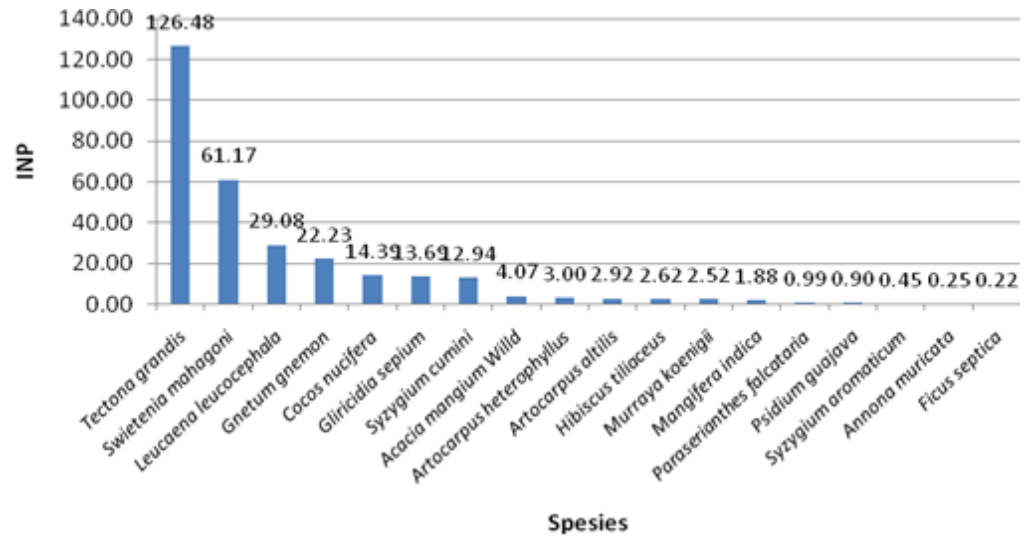

Figure 1. Graphic of averaged INP of tree strata in every study area 
Based on the study result which has been done in Ancient volcano Mujil Kulon Progo region, 18 tree strata vegetation types have been obtained. Teak (Tectona grandis) is the tree strata vegetation with the highest INP with average $126.48 \%$ and is found in all of the study area. The high INP value of this vegetation is because that this vegetation is purposely planted by the local people and its benefits are taken. Based on [4] Tectona grandisis able to live with temperature about $22^{\circ} \mathrm{C}-31^{\circ} \mathrm{C}$ with rainfall rate between 1200-3000 mm/year, light intensity around $75-100 \%$, and is able to grow well in elevation about 0-700 msl. Based on Sumarna [5] teak needs a minimum temperature about $13^{\circ} \mathrm{C}-17^{\circ} \mathrm{C}$ and maximum temperature between $39^{\circ} \mathrm{C}-43^{\circ} \mathrm{C}$, and could grow well in optimum temperature of $32^{\circ} \mathrm{C}-42^{\circ} \mathrm{C}$. The environment humidity that is needed by Tectona grandis is about $80 \%$ for the vegetative phase and 60 $70 \%$ for generative phase and soil $\mathrm{pH}$ needed is around 6.5-7. Based on the abiotic measurement result, it can be known that temperature, humidity, and soil $\mathrm{pH}$ which are suitable for the teak growth with the study area value A have air temperature of $31.9^{\circ} \mathrm{C}$, study area value $\mathrm{B}$ with $33^{\circ} \mathrm{C}$, and study area value $\mathrm{C}$ with $29.7^{\circ} \mathrm{C}$, and averaged soil temperature of study area $\mathrm{A}, \mathrm{B}$, and $\mathrm{C}$ are $28.3^{\circ} \mathrm{C}, 28.9^{\circ} \mathrm{C}, 28.1^{\circ} \mathrm{C}$, respectively, air humidity of study area $\mathrm{A}$ with $66.7 \%$, $60 \%$ for study area $C$, and $71.1 \%$ for study area $C$, soil humidity of study area A has a value of $68.7 \%$, study area $\mathrm{B}$ with $59.1 \%$, and study area $\mathrm{C} 61 \%$. The averaged $\mathrm{pH}$ for study area $\mathrm{A}$ is 6.46 , study area B with 6.21 , and study area $\mathrm{C}$ with 6.28

The tree strata vegetation type with the second highest IV after teak is mahogany (Swietenia mahagoni) with averaged INP value with $61.17 \%$. Swietenia mahagoni has the second highest because it is a commodity that is planted by the local people around Ancient volcano Mujil. Based on (Mindawati \& Megawati, 2013) mahogany (Swietenia mahagoni) is a vegetation that easily adapt with various soil types starting from arid land to marginal land. Swietenia mahagoniis able to optimally grow if it is placed in a place with soil $\mathrm{pH}$ 6.5-7.5, maximum elevation of 1000-1500 msl. Based on Lemmens [6] mahogany (Swietenia mahagoni) is able to grow in an averaged temperature of $20^{\circ} \mathrm{C}-28^{\circ} \mathrm{C}$ and grow well in lowlands until $1500 \mathrm{msl}$ (mean sea level) on various soil types that are free of puddle and $\mathrm{pH}$ 6.5-7.5. The result of abiotic factor measurement such as temperature and soil $\mathrm{pH}$ are suitable for the growth of mahogany such as averaged soil temperature of study area $\mathrm{A}$ has a value of $28.3^{\circ} \mathrm{C}$, the study area $\mathrm{B} 28.9^{\circ} \mathrm{C}$, study area $\mathrm{C}$ $28.1^{\circ} \mathrm{C}$ and averaged $\mathrm{pH}$ for study area A 6.46, study area B 6.21, and study area $\mathrm{C}$ with 6.28 .

Awar-awar vegetation (Ficus septica) has the lowest INP in all of the study area with averaged INP of $0.22 \%$. Awar-awar (Ficus septica) is part of the moraceae family. The low IV is because Ficus septica has low density, dominance, and frequency in the area. This happens in Ancient volcano Mujil because the local people look for the animal feed by using this vegetation, resulting the decrease of the Ficus septic population. Based on [7] Ficus septic which is part of the moraceae family could bear against a low $\mathrm{pH}$ (acid soil) with $\mathrm{pH}$ of 6.0-7.5 but could also optimally grow in $\mathrm{pH}$ ranging from 6-7 with minimum temperature of $16^{\circ} \mathrm{C}-21^{\circ} \mathrm{C}$ and maximum temperature around $31^{\circ} \mathrm{C}$ $31.5^{\circ} \mathrm{C}$ and is also able to grow with humidity of 50 $90 \%$. Based on this result, it can be concluded that the soil $\mathrm{pH}$, humidity, and temperature in Ancient volcano Mujil region are suitable for the growth awar-awar (Ficus septica)growth such as averaged soil temperature in study area $\mathrm{A}, \mathrm{B}$, and $\mathrm{C}$ with $28.3^{\circ} \mathrm{C}$, $28.9^{\circ} \mathrm{C}$, and $28.1^{\circ} \mathrm{C}$ respectively, and air humidity of study area A with $66.7 \%$, 60\% for study area B, and $71.1 \%$ for study area $\mathrm{C}$, and also the soil temperature of study area A with $68.7 \%$, study area B with $59.1 \%$, and $61 \%$ for study area $\mathrm{C}$. The averaged $\mathrm{pH}$ for study area A is 6.46 , study area B 6.21, and 6.28 for study area $\mathrm{C}$

The tree strata vegetation type that has the second lowest IV after Ficus septica is soursop or Annona muricata $L$ with INP of $0.25 \%$. Based on [8] the soursop in Indonesia can grow well in the low to highland (elevation of $1000 \mathrm{msl}$ ). Based on Radi [9] the good air temperature for soursop growth ranges from $25^{\circ} \mathrm{C}-32^{\circ} \mathrm{C}$. The ideal location for soursop plant is an open land with no shade that covers the soursop. Soursop plant needs sunlight between $50-70 \%$. Soursop is able to optimally grow in the suitable rainfall rate which ranges from 1,500-2,000 mm/year with 4-6 months dry season. The good soil for soursop plant needs to have $\mathrm{pH}$ between 5.5-7 [10]. This plant could grow optimally in elevation reaching $1200 \mathrm{msl}$, and also the air temperature of $22^{\circ} \mathrm{C}-28^{\circ} \mathrm{C}$, with humidity and rainfall rate around 1500-2500 $\mathrm{mm} /$ year. The result shows that the abiotic conditions which are temperature, humidity, and soil $\mathrm{pH}$ which are suitable for the soursop growth are the air temperature of $31.9^{\circ} \mathrm{C}$ in study area $\mathrm{A}, 33^{\circ} \mathrm{C}$ in study area $\mathrm{B}$, and $29.7^{\circ} \mathrm{C}$ for study area $\mathrm{C}$, and the air humidity of $66.7 \%$ in study area A, $60 \%$ in study area $\mathrm{B}$, and $71.1 \%$ in study area C. Furthermore, the suitable soil humidity in study area $\mathrm{A}, \mathrm{B}$, and $\mathrm{C}$ are $68.7 \%, 59.1 \%$, and $61 \%$, respectively, while the suitable $\mathrm{pH}$ in study area $\mathrm{A}$ is 6.46 , study area B with 6.21, and 6.28 for study area C. However, the abundance of shades in the region hamper the optimum soursop plant growth.

2. Diversity index in vegetation types of tree strata in all study area

Diversity Indexes in vegetation types of tree stratain all area are shown in Figure 2 


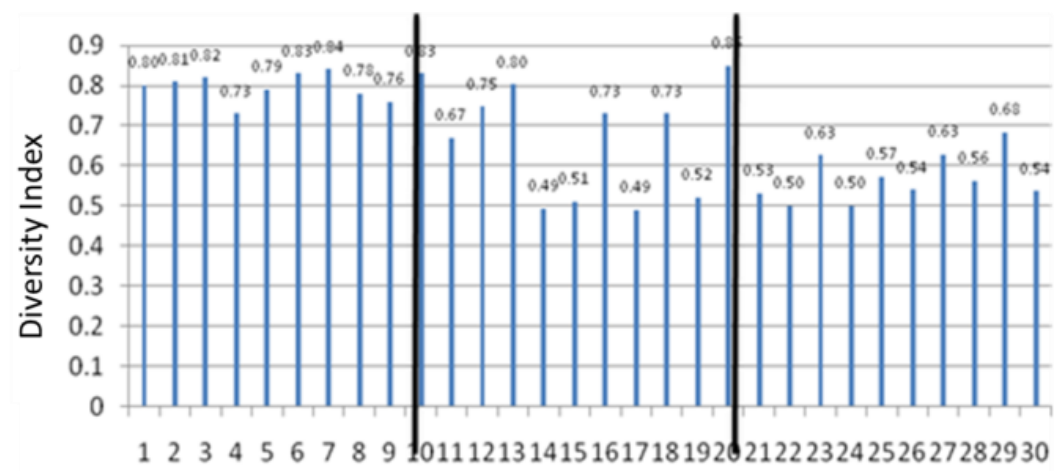

Study Area A

Study Area B

Study Area C

Figure 2. Graph of Diversity in Vegetation Types of Tree Stratain All Study Area

The graph above shows thatthe diversity indexin vegetation types of tree strata in all study area has a low diversity index with a range of 0.57-0.82. ShanonWeiner [11] stated that $H^{\prime}<1$ value shows diversity index of a species is low, this is because the vegetation spread only dominates several regions which is shown by the low diversity index. and "" [12][13] also stated that the diversity of vegetation types is the type's abundance weighted by the evenness of the variety. In this study, the type of tree strata vegetation has a high species richness, but 18 types of vegetation strata are unevenly scattered that cause the evenness of vegetation becomes lower.The low evenness of tree strata vegetation types is proven by the total averaged relative frequency of 18 tree strata vegetation types in all study area which has a value of $5.6 \%$, it adversely affects the low diversity index of tree strata vegetation in Ancient volcano Mujil Kulon Progo region.
Although the overall number of species of plants in the region is abundant ( 18 species) but the diversity index of tree strata vegetation is low. this is caused by vegetation distribution that only dominates several areas which is reflected from the low frequency value. [14] mentioned that when the diversity of species in a vegetation is low, it may happen because the area is dominated by specific plants. The low diversity index can also be caused by uneven distribution of species in each study area. Based on [15][16][17][18] Diversity is synonymous with ecosystem stability, if the diversity of an ecosystem is high, then the condition of the ecosystem tends to be stable and low diversity reflects instability.

3. The measurement result of abiotic environmental factors

The measurement resultsof abiotic environmental factorsare shown in Table 1below:

Table 1. The result of averaged abiotic condition measurement in all study area

\begin{tabular}{|l|c|c|c|}
\hline \multicolumn{1}{|c|}{ Abiotic Factors } & Study Area A & Study AreaB & Study AreaC \\
\hline Air temperature & $31.9^{\circ} \mathrm{C}$ & $33^{\circ} \mathrm{C}$ & $29.7^{0 \mathrm{C}}$ \\
\hline Soil temperature & $28.3^{\circ} \mathrm{C}$ & $28.9^{\circ} \mathrm{C}$ & $28.1^{\circ} \mathrm{C}$ \\
\hline Air humidity & $66.7 \%$ & $60 \%$ & $71.1 \%$ \\
\hline Soil humidity & $68.7 \%$ & $59.1 \%$ & $61 \%$ \\
\hline Soil pH & 6.46 & 6.21 & 6.28 \\
\hline Light intensity & 795.9 & 674.2 & 667.7 \\
\hline
\end{tabular}

Table 1 shows that there are differences in measured abiotic environmental conditions which includes air temperature, air humidity, soil moisture, soil $\mathrm{pH}$ and light intensity in each study area. The highest air temperature was in study area A with $31.90^{\circ} \mathrm{C}$, the highest soil temperature was in study b area with $28.90^{\circ} \mathrm{C}$, the highest air humidity was in study area $\mathrm{C}$ with $71.1 \%$, The highest soil moisture was in study area A with $68.7 \%$, the highest soil $\mathrm{pH}$ was found in Study area A with 6.46 and the highest light intensity was in Study area A with $795.9 \%$.

4. Results of cluster analysis

The calculation results of cluster analysis to determine the linkages between measurable abiotic environmental conditions with the stand grouping pattern is shown in Table 2 below: 
Table 2. Results of Cluster analysis abiotic environmental conditions in the Mount Mujil area ANOVA

\begin{tabular}{|l|r|r|r|r|r|l|}
\hline & \multicolumn{3}{|l|}{ Cluster } & \multicolumn{2}{l|}{ Error } & \multirow{2}{*}{ Sig. } \\
\cline { 2 - 6 } & $\begin{array}{c}\text { Mean } \\
\text { Square }\end{array}$ & Df & $\begin{array}{c}\text { Mean } \\
\text { Square }\end{array}$ & df & & \\
\hline Air temperature & 3.392 & 1 & 3.717 & 28 & .913 & .348 \\
Soil temperature & .199 & 1 & 1.113 & 28 & .179 & .676 \\
Air humidity & 7.792 & 1 & 36.146 & 28 & .216 & .646 \\
Soil humidity & 234.388 & 1 & 13.981 & 28 & 16.7 & .000 \\
Soil pH & .219 & 1 & .027 & 28 & 8.02 & \\
& 115645. & 1 & 2164.2 & 28 & 53.4 & .008 \\
Light intensity & 125 & 1 & 17 & 35 & .000 \\
\hline
\end{tabular}

The results of cluster analysis show that abiotic factors related to the grouping stand pattern are soil humidity, soil $\mathrm{pH}$ and light intensity with $0.000,0.008$ and 0.000 respectively. While other abiotic factors such as air temperature, soil temperature and humidity are not related to the stand grouping pattern with values of $0.348,0.678$ and 0.646 , consecutively. If the significance $<\alpha(0.05)$ then $\mathrm{H} 0$ is accepted (the measured abiotic factors are related to the grouping stand pattern) and if the significance $>\alpha(0.05) \mathrm{H} 0$ is rejected (the measured abiotic factors are not related to the grouping stand pattern).

5. Discussion of the potential of the research to be used as a biology learning source in first grade of high school in the biodiversity subject in ecosystem level

The research result of vegetation types' tree stratain Ancient volcano Mujil, Kulon Progo, is analyzed to be a learning source on biodiversity at the ecosystem level forfirst grade high school based on requirements from Djohar [2] such as 1) clarity of potential and availability with issues raised. The potential object in this study is the type of tree strata vegetation and the problem raised is the lack of contextual examples of high school biodiversity in the high school's first grade. 2)The suitability of this results with the learning objectives in the 2013 curriculum, especially KD 3.2 is that the students can mention the types of vegetation in the strata of trees, learners can mention the examples of plant species that have the highest and lowest role (IV) in the Ancient volcano Mujil, Kulon Progo area, students can explain the concept of biodiversity at the ecosystem level.

3) Clarity of material objectives and their purpose. The subject's objective in this study is Biodiversity ecosystem level, while the target designation is for high school learners in the first grade. "'Based on [19] The function of this learning source to make it easier to achieve the subject goals and improve learning outcomes to achieve learning competence. 4) Clarity of information that can be explained. Based on the research in Ancient volcano Mujil Kulon progo area, a research product is obtained. This research products are in the form of facts and concepts. The facts found are 18 types of tree strata vegetationin Ancient volcano Mujil region with obtained data on measurable environmental conditions including air temperature, soil temperature, air humidity, soil moisture, soil $\mathrm{pH}$, and light intensity in order to obtain the concept of biodiversity at the ecosystem level. [20] stated that based on the analysis of the process and research product of the attractant compound Ocimum basilum $\mathrm{L}$ against flies can be used as a learning resource for the high school's second grade students. 5) The clarity of exploration guidance, it is known that this study is based on the work procedure or exploration guidance which is coherent and clear. The work procedure starts from the choice of the research area, research object, work flow, tools, data analysis and conclusion making. 6) The clarity of the result reached such the accomplishment of the learning objectives that are expected to increase three aspects such as cognitive, affective, and psychomotoric. Based on [21] the value of local wisdom in Ngata Toro society in managing the forest resources can be utilized as a interactive learning source between human and environment. The utilization of school environment to prepare the local-wisdom based biology learning source is highly potential to increase the value and attitude of the learning members. Furthermore [22] stated that a learning with environmental basis with abundance of resources can increase and develop the knowledge and skill of the students effectively.

Besides the biology learning source requirement by Djohar [2] above, this potential of this study to be a learning source based on the criteria is also analysed based on Dick\&Carey [23] such as 1) the availability of the surrounding source. The Ancient volcano Mujil 
has various vegetations of tree strata that can be used as a learning source for ecosystem-level diversity subject. The biology phenomenon happened in the environment of the student gives a chance to the students for doing innovations in a local-wisdom based education [24]. 2) the availability of fund, manpower, and the facilities which are adequate to hold a learning source. In this study, the fund and manpower needed in the Ancient volcano Mujil Kulon Progo as a learning source of biodiversity subject on ecosystem level are relatively low. This is due to the distance between the Ancient volcano Mujil with the education area (school) which is quite close, so that it can save the budget, transportation, and energy. The facilities used to support the Ancient volcano Mujil as a learning source is quite simple such as ruler, thermometer, hygrometer, soil tester, and observation table. 3) Flexibility factor, practicality, and the endurance of the learning source for a quite long period. This study shows that this region does not need complex processes and stages to be made as a learning source and is easy to conduct an observation. Furthermore, the sustainability of this area that is still preserved makes it possible for the Ancient volcano Mujil region to be used as a long-term learning source. 4) The effectiveness of the cost in the long-term period. The fund needed to make the Ancient volcano Mujil to become a learning source is relatively cheap and effective. This is because the location of the Ancient volcano Mujil is easy to access and its utilization as a learning source does not need any complex, so that it saves the cost needed.

Based on the analysis result of the potential of the learning source based on the requirements by Djohar [2] and Dick\&Carey [23], it can be stated that his research result has potential to be made as a learning source for biologuy subject in first-grade high school in ecosystem-level biodiversity subject. According to the results, it is potential to be used as learning materials for first grade senior high school. The aspects include object availability and the issues in question; suitability with the learning objectives; aims and purposes; information clarity; exploration guidelines; and the outcome [25][26][27] Most senior high school biology teachers $(64.0 \%)$ say that natural resources available on land in East Kalimantan such as, mining products, plantations can be used as learning media for senior high school biology learning [28].

\section{CONCLUSION}

Based on research of tree strata vegetation in ancient volcano Mujil Kulon Progo as a learning resource material Biology biodiversity ecosystem level for first grade senior high school, it can be concluded:

1. The highest importance index (IV) are Tectona grandis with an INP value of $126.48 \%$ and the lowest INP found in Ficus septica plants with a value of $0.22 \%$ found in Ancient volcano Mujil region which has 18 types of tree strata vegetations.
2. The diversity of tree strata vegetation in Ancient volcano Mujil Kulon Progo region has a relatively low criteria indicated by the value of $\mathrm{H}^{\prime}$ ranging from 0.49 to 0.85 .

3. Based on cluster analysis, the stand grouping pattern is divided into Cluster 1 and Cluster 2. Environmental factors related to the stand grouping pattern are soil moisture, soil $\mathrm{pH}$, and light intensity while air temperature, soil temperature and air humidity are not related.

4. Based on the research, it can be concluded that the diversity of tree strata vegetation in Ancient volcano Mujil Kulon Progo area has the potential to be a place to learn biology first grade senior high school students on biodiversity at the ecosystem level.

\section{ACKNOWLEDGMENT}

This Research wash supported by Universitas Ahmad Dahlan (UAD) and the LPPM of Universitas Ahmad Dahlan

\section{REFERENCES}

[1] H. G. Hartono and S. Pambudi, "Gunung Api Purba Mujil, Kulonprogo, Yogyakarta: Suatu Bukti Dan Pemikiran," Pros. Semin. Nas. ReTII ke-10, pp. 7176, 2015.

[2] Suhardi, Pengembangan sumber belajar biologi. Yogyakarta: Universitas Negeri Yogyakarta, 2012.

[3] T. Handayani, Petunjuk Praktikum Ekologi Tumbuhan. Yogyakarta: Universitas Ahmad Dahlan, 2019.

[4] S. Pudjiono, Produksi Bibit Jati Unggul dari Klon dan Budidayanya. Bogor: IPB Press, 2014.

[5] I. Asmayannur, Chairul, and Z. Syam, "Analisis Vegetasi Dasar di Bawah Tegakan Jati Emas ( Tectona grandis L .) dan Jati Putih ( Gmelina arborea Roxb .) di Kampus Universitas Andalas," J. Biol. Univ. Andalas, vol. 1, no. 2, pp. 173-178, 2012.

[6] Nursyamsi and Suhartati, "Pertumbuhan Tanaman Mahoni (Swietenia macrophylla King ) dan Suren (Toona sinensis ) DI Wilayah DAS Datara Kab. Gowa," Info Terkini Eboni, vol. 10, no. 1, pp. 4857, 2013.

[7] Hasanuddin, "Jenis Tumbuhan Moraceae di Kawasan Stasiun Ketambetaman Nasional Gunung Leuser Aceh Tenggara," Semin. Nas. Biot., vol. 4, pp. 45-50, 2017.

[8] Nuswarmarhaeni and Saptarini, Mengeal buah unggul Indonesia. Jakarta: Penebar Swadaya, 1999.

[9] G. A. T. Masito, D. W. Respatie, and R. Rogomulyo, "Pengaruh Lima Macam Pupuk 
Organik Terhadap Pertumbuhan dan Kandungan Senyawa Aktif Daun Sirsak (Annona muricata L.),"Vegetetalika, vol. 3, no. 3, pp. 97-105, 2014.

[10] Sunarjono, Prospek Berkebun Buah. Jakarta: Penebar Swadaya, 1997.

[11] F. Fachrul, Melati, Metode sampling bioekologis. Jakarta: Bumi Aksara, 2012.

[12] S. Hardjosuwarno, Dasar-dasar ekologi tumbuhan. Yogyakarta: Universitas Gadjah Mada, 1990.

[13] J. Sureshkumar, M. Ayyanar, and R. Silambarasan, "Pteridophyte species richness along elevation gradients in Kolli Hills of the Eastern Ghats, India," J. Asia-Pacific Biodivers., vol. 13, no. 1, pp. 92106, 2020.

[14] Indriyanto, Ekologi hutan. Jakarta: Bumi Aksara, 2008.

[15] E. . Odum, Dasar-dasar ekologi Ed.3. Yogyakarta: Universitas Gadjah Mada Pres, 1998.

[16] F. P. Werneck, C. Nogueira, G. R. Colli, J. W. Sites, and G. C. Costa, "Climatic stability in the Brazilian Cerrado: Implications for biogeographical connections of South American savannas, species richness and conservation in a biodiversity hotspot," J. Biogeogr., vol. 39, no. 9, pp. 1695-1706, 2012.

[17] N. Yuniar and N. F. Haneda, "Keanekaragaman semut ( Hymenoptera: Formicidae ) pada empat tipe ekosistem yang berbeda di Jambi Ants diversity in four different ecosystem type in Jambi," Pros Sem Nas Masy Biodiv Indon, vol. 1, pp. 1582-1585, 2015.

[18] S. Pironon, G. Papuga, J. Villellas, A. L. Angert, M. B. García, and J. D. Thompson, "Geographic variation in genetic and demographic performance: new insights from an old biogeographical paradigm," Biol. Rev., vol. 92, no. 4, pp. 18771909, 2017.

[19] B. L. Ong'amo, S. R. Ondigi, and A. Omariba, "EEffect of utilization of Biology teaching and learning resources on students' Academic Performance in Secondary Schools in Siaya District - Kenya," Int. J. Educ. Res., vol. 5, no. 1, pp. 253-272, 2017.

[20] N. Eurika and A. N. Akhmadi, "the Study of Basil Flower Attractant (Ocimum Basilicum) Towards
Fruit Flies As Biology," vol. 1, no. July, pp. 28-36, 2016.

[21] Yuliana, S. Sriyati, and Y. Sanjaya, "Local wisdom of Ngata Toro community in utilizing forest resources as a learning source of biology Local Wisdom of Ngata Toro Community in Utilizing Forest Resources as a Learning Source of Biology," 4th Int. Conf. Res. Implementation, Educ. Math. Sci. (4th ICRIEMS AIP Conf. Proc. 1868, 1000071-100007-9; doi 10.1063/1.4995217 Publ. by AIP Publ. 978-0-7354-1548-5/\$30.00, vol. 100007, no. August, 2017.

[22] H. Jeong and C. E. Hmelo-silver, "Productive use of learning resources in an online problem-based learning environment," Comput. Human Behav., vol. 26, no. 1, pp. 84-99, 2010.

[23] Supriadi, "Pemanfaatan Sumber Belajar Dalam Proses Pembelajaran," Lantanida J., vol. 3, no. 2, 2015.

[24] D. Anazifa and R. . Hadi, "The Integration of Javanese Indigenous Knowledge in Biology Learning Resources Development The Integration of Javanese Indigenous Knowledge in Biology Learning Resources Development," J. Phys. Conf. Ser., pp. 1-5, 2017.

[25] T. Handayani and N. Hidayat, "Analysis of Tree Stratum Vegetation in Sand Dune Core Zone in Parangtritis Village Kretek Sub-District Bantul Regency Yogyakarta As Learning Sources on Biodiversity for Grade X Senior High School," 2019.

[26] T. Handayani, M. S. Wibowo, and D. Sulisworo, "Earthworm (Oligochaeta) diversity in the region of the ancient Volcano, Nglanggeran, Yogyakarta as a learning resource of biology lesson," Int. J. Sci. Technol. Res., vol. 8, no. 10, pp. 1013-1018, 2019.

[27] T. Handayani, H. K. E. P. Moro, and L. B. Utami, "Association of Herbaceous Species on the Sand Dunes of Parangtritis Yogyakarta as Biology Learning Resource," vol. 422, no. Icope 2019, pp. 242-245, 2020.

[28] D. T. Boleng and S. V. T. Lumowa, "Responses of biology teachers of senior high school about utilization the local natural resources as learning media at Samarinda city," AIP Conf. Proc., vol. 2120, no. July, 2019. 